\title{
PUBLIC INTEREST IN FINANCIAL LAW OF THE REPUBLIC OF BELARUS: THEORY AND PRACTICE
}

\author{
LILIYA ABRAMCHIK ${ }^{1}$
}

\begin{abstract}
In the scientific work the analysis of interaction and boundaries of public and private interest in financial law, from the point of view of both doctrine and law enforcement, was carried out. The absence of public interest concept in financial, budget, tax legislation of the Republic of Belarus was paid attention to. It was suggested that the concept of public interest should be enshrined in financial law at the statutory level. The following works of scientists in the field of financial, tax and budget law served as methodological basis for writing the work: E.Yu. Gracheva (2014), Yu.P. Gavrilchenko (2016), M.V. Karasev (2006), Yu.A. Krokhina (2012), S.K. Leshchenko (2008), O.A. Nogina (2012), A.A. Pilipenko (2006), N.A. Povetkina (2015), N.A. Sheveleva (2009), E.V. Chernikova (2016), and others. In the research process both general scientific and particular methods were used: synthesis and analysis, collection and generalization of different points of view of scientists, comparative, system, comparative legal, logical-juridical, structuralfunctional analysis.
\end{abstract}

\section{Keywords}

Public interest; budgetary activity; financial law; tax law; private interest; tax administration

JEL Classification: K34, K39, D63

1 Candidate of Juridical Sciences, associate professor, Educational institution Yanka Kupalthe state University of Grodno, Doctoral (higher doctorate degree) candidate of Saint Petersburg State University, author of more than 100 scientific works. Contact email: lilia_abramchik@mail.ru. 


\section{Introduction}

The aim of the law is to provide stability of social relations by ensuring the balance of public and private interests. The relevance of the raised issue is determined by the following factors:

- firstly, by the objective need for theoretical comprehension and enshrinement in the Belarusian legislation of the principle of balance of public and private interests as a regulator of relations in the "state-society" system as the most important condition for stable democratic development of society and the state;

- secondly, by the need for legislative enshrinement of "public interest" concept and features of public interest in financial law;

- thirdly, by the search for conditions and ways to harmonize the spheres of public interests, state and private interests, boundaries of their satisfaction and limitation;

- fourthly, by the solution of the problems of doctrinal development and the legal-regulatory consolidation of fundamentals, ensuring compliance with this principle in all areas of legally significant activity.

In the national and foreign scientific literature there are a number of works devoted to certain aspects of the problem of observing the balance of public and private interests. The issue was addressed by: S.S. Alekseev (1995), T.S. Boiko (2011), A.V. Bryzgalin (1997), G.A. Vasilevich (2005), V.A. Vitushko (2001), E.Yu. Gracheva (2014), Yu.P. Gavrilchenko (2016), O.S. Ioffe (19750), M.V. Karaseva (2006), Yu.A. Krokhina (2014), S.K. Leshchenko (2008), A.V. Malko (2014), V.A. Maltsev (2011), M.N. Marchenko (2015), O.A. Nogina (2012), A.A. Pilipenko (2006), N.A. Povetkin (2015), A.M. Rabets (2016), L.N. Ryabtsev (2013), Yu.A. Tikhomirov (1995), N.A. Sheveleva (2009), G.F. Shershenevich (1995), E.V. Chernikova (2016) and others.

However, until now there is no clear understanding of the ways and means for ensuring the balance of public and private interests in various areas of legal regulation, including in the field of financial law. Legal science needs specification and concretization of theoretical positions on a number of issues relating to the concept under investigation.

In the research process both general scientific and particular methods were used: synthesis and analysis, collection and generalization of different points of view of scientists, comparative, system, comparative legal, logical-juridical, structuralfunctional analysis. 


\section{Theory of Public Interest in Financial Law}

The social value of law lies in the fact that it is designed to regulate the widest range of social relations, both from the point of view of social interest and for the sake of fulfilling public interests. In the legal literature public interests are fairly divided according to different grounds: economic, related to the production, distribution and consumption of financial resources, material wealth; political, underlying the management of the state, implementation by the state power of its functions; spiritual, connected with spiritual values, products of spiritual creativity - morality, science, art; social (Tikhomirov, 1995).

The state is the fundamental participant of public relations, the specificity of legal status of which consists in determining, acquiring of its legal personality, establishing of legal regulation method (imperative or dispositive) of one or another legitimate interest, the ways of their protection, sanctions, the limits of their implementation. Therefore, the purpose of the law is in balancing of interests in society, in finding a compromise between them through relevant regulatory legal acts that serve as the means of external expression of public interest, and in provision of a mechanism for their implementation.

In the Preamble of the Constitution of the Republic of Belarus, the main ideas, and principles, by which people and power should be guided them in the process of state-building and social development, are formulated. It is responsibility for the current state and the future of Belarus; awareness of being a full-fledged subject of the world community, an inalienable right to self-determination; reliance on the centuries-old history of the development of the Belarusian statehood; the assertion of the rights and freedoms of every citizen; ensuring civil consent and unshakable foundations of democracy and the law-governed state. The second section of the Constitution of the Republic of Belarus "Individual, society, state" fixes personal, political, socio-economic and cultural rights and freedoms of citizens, defines the duties of citizens, the state's responsibility to society and individual, its responsibility to provide material guarantees and opportunities for the full exercise of rights and freedoms of citizens. Therefore, the state becomes a speaker of public interest when implementing its activities. A particular difficulty in the process of implementing financial activity of state, or more precisely, in the process of raising, distributing and using of funds and setting its goals, is the procedure of determining what interests at a certain point in time can obtain a legal regime of state regulation for the sake of fulfilling public interests. The main directions of social and economic development of the Republic of Belarus for 2016-2020 contain tasks that need to be realized from the point of view of public (social) interest (The set of measures for 
the implementation of the main directions of socio-economic development of the Republic of Belarus for 2016-2020).

The realization of state interests is possible through the actions of the state itself represented by appropriate authorities and also through the activity of other subjects, including tax authorities, banks, insurance companies, as a special type of legal entities, state institutions, unitary enterprises, state corporations, and in other ways. The most important is the ability of a public subject to express public interest through an integrated system of administration and, in our opinion, particularly tax administration, since the largest number of concerned parties are affected. It is important here to be able to maintain the balance, the boundaries of public and private interests.

Having examined various scientific doctrines, we became convinced that the very concept of public interest is controversial: the content of homogeneous public interests does not always coincide, and homogeneous interests themselves do not always form a commonality. For instance, Yu.A. Tikhomirov writes that public interests as a concentrated expression of general social needs and aspirations act as a backbone phenomenon and from the legal point of view is characterized by certain regulatory features by fixing its priority, establishing order and guarantees of provision, fixing the ways of protection and measures of responsibility. The common generic concept of "public interest" is combined with specific normative concepts - "interests of society and state", "national security", "common interests", "interests of nations, peoples, population", "general economic interests", "interests of ecological well-being" "regional and local interests", "corporate interests". In his opinion, public interest, in its concentrated form, is enshrined in the Constitution and serves as a legal basis for all branches of law, being at the same time an object of reflection and enshrinement in the private law branches (Tikhomirov, 1995). Professor L.N. Ryabtsev and D.V. Gvozdev point out that public interests are subjective interests, the implementation of which is entrusted to the state represented by its apparatus. At the same time, the security is a subjective need, which is realized through the implementation of law enforcement function (Ryabtsev, Gvozdev, 2013: 145). Therefore, public interests are the interests of society and state. We should agree with the definition of public interest, suggested by Yu.A. Tikhomirov - "a general social interest that in a concentrated form reflects the entire spectrum of interests in society" (Tikhomirov, 1995).

It is important for us to determine the nature of public interest in financial law. To define whether it meets the long-term needs of society. Despite the fact that the concept of "public interest" is not enshrined in financial legislation, the components of public interest of state are not only enshrined in the regulations of financial legislation, but the Constitutional Court of the Republic of Belarus 
in a number of acts emphasizes the public interest of the state. For example, the Constitution, fixing the duty of citizens of the Republic of Belarus to participate in the financing of public expenditures by paying state taxes, duties and other payments, does not directly provide for a legal mechanism for the fulfillment of this duty. The Constitutional Court, when reviewing regulatory legal acts in the sphere of tax legislation, expressed legal positions, the essence of which is that a constitutional obligation to pay taxes has a special public legal nature, conditioned by the public legal nature of state and state power; taxes, duties, and fees are a prerequisite for the existence of any state, so the obligation to pay them applies to all taxpayers as an unconditional requirement; tax payments are the main source of revenue part of the budget and the most important guarantee of national interests protection in the sphere of financial activity; only if the budget is sufficiently filled with funds, state is able to carry out its functions and solve its tasks (Constitutional Court no. P-412/2009, Constitutional Court no. P-962/2014, Constitutional Court no. P-1017/2015, etc.). When investigating the financial activities of the state, Yu.A. Krokhina acknowledges that it is public in nature, since it provides the flow of funds in the interests of the whole society (Krokhina, 2014: 67).

However, public interests may coincide with the interests of the state and in this case become a part of state interests. In other occasions, the state may allow their implementation in the framework of lawful activities or may fight against them, establish a ban on their implementation. In a number of cases the state from the perspective of the long-term interests of society, tasks concerning the development of certain spheres of public activity, promotion of economic stability and social progress may realize its state interests, sometimes not shared by society. For example, the state may implement so-called unpopular measures, for instance, increase tax rates, reduce tax exemptions, introduce new fees, etc. Thus, not every social interest can become an interest for the state. But it is public interest in financial law that is aimed at the benefit of society and the development of the state.

While carrying out financial activities, the state simultaneously acts as both a subject of public authority and the owner of its own (state) property, therefore public interest recognized by state and secured by law serves as a condition and guarantee for the existence and development of state itself. Without financial resources, it is impossible to ensure the implementation of functions of the state. Public interest should act as a guarantor of the society development. Thus, it is possible to give the following definition of the concept of "public interest in financial law": social interests recognized by the state, expressed in the rules of financial law and provided with the mechanism of state coercion allowing the development of society and the state. Thus, the diversity and multiplicity of functions performed by modern states as well as the incoherence and 
inconsistency of the goals of various state policies (tax, budget, social, scientific and others) cause plurality and diversity of public interests.

\section{Public Interest in Budget Law}

Legal regulation of budgetary relations is an important task and, along with problems of legal regulation of public and private interests, belongs to one of the acutest problems of the world community, requiring study and solution in each state. At the same time, to protect its own interests, the state legislatively fixes funds that allow it to regulate budgetary relations, providing for its own property interests, property and non-property interests of its citizens. All this is an expression of interests of state and other public subjects. Therefore, for the objective of our research we will proceed from the theoretical provisions of the previous chapter that at the present time it is public interest of the state that is traced through proprietary rights: the right to finance - money, the right of state and municipal property, and also a number of non-proprietary interests express public interests in budgetary sphere. Budget law is the aggregate of legal rules governing relations that arise between subjects of budgetary legal relations in the process of income generation, its distribution and use in the budgetary system of the Republic of Belarus, implementation of state and local borrowings, regulation of state debt as well as relations between subjects of budgetary legal relations in the budget process. Budget control is an important direction in the public interest of the state.

It is public interest in the budget law that allows its citizens to receive necessary benefits from the state through the performance of functions by state bodies. The state, by establishing legal rules reflecting certain interests, enables the subjects of budget law to acquire necessary legal means for the realization of their subjective rights, which ensures a combination of public and private interests. In the norms of the Budget Code of the Republic of Belarus, budget obligations are fixed as expenditure obligations received and accepted by the recipient of budgetary funds and (or) subjected to execution in the corresponding financial year from the funds of the corresponding budget (Budget Code, Art. 2). The state guarantees financial security through expenditure obligations - obligations of the Republic of Belarus, the administrative-territorial unit of the Republic of Belarus or the recipient of budgetary funds acting on their behalf, determined by the Law of the Republic of Belarus, Act of the President of the Republic of Belarus, the agreement concluded on behalf of the Republic of Belarus, its administrative-territorial unit, the resolution of the Government of the Republic of Belarus, the decision of the local Council of Deputies, local executive and regulatory body, to provide a resident and (or) non-resident of the Republic of Belarus with funds from the relevant budget 
(Budget Code, Art. 1/461). At the same time, budgetary allocations are directed to the social provision of the population, provision of social payments to citizens or purchasing of goods, works, services in favor of citizens to ensure their needs in order to implement social support measures for the population, to realize socially significant state programs.

Thus, state assumes public obligations - expenditure obligations of public-law entity, determined by law, other regulatory legal act, to a natural or legal person, another public-law entity, subjected to enforcement in the amount established by the relevant law, other regulatory legal act or having a method for determining it, established by a corresponding act (calculation, indexation).

It should be noted that the subjects of budget law have a very definite interest in using budgetary funds for the benefit of the development of society and each individual. Social, economic and other common needs are recognized as social and public in the analyzed situation. The state in this interpretation acts not as an independent subject of social relations, but only as a representative of the interests of society, Authorized to perform functions through budgetary activities in general. At the same time, one should not forget and bear in mind that when resolving disputes, that it is necessary to accurately qualify the norms that are subjected to direct application for the implementation of public and private interests in the budget law.

\section{Public Interest in Tax Law of the Republic of Belarus}

Taxes, being an attribute of state, in addition to the fact that they touch the foundations of the constitutional order of the state, they also concern the entire system of human and citizen rights and freedoms. The inviolability of private property, protection of human rights and freedoms enshrined in the Constitution determines the importance of tax law from the position of both public and private subjects. Modern tax law comes not only from public interests of the state through the implementation of fiscal tasks but also from the private interests of natural and legal persons participating in civil circulation through tax incentives. Since tax regulation is mainly fiscal in its nature, taxation is characterized by giving priority to public interests over private ones. Legal principles of a tax system of a particular state fully reflect correlation of private and public interests.

In the tax law science it is not only issues of correlation between private and public interests, but primarily the concepts themselves approach to their definition that causes discussion. As a theory of law (Karaseva, 2006) the tax law expresses different points of view regarding the content of the concept of public interest. Khimicheva N.I. pointed out that private interests lie in: reducing of tax burden; 
return of taxes in the form of social benefits; protection of property rights of a private subject; application of tax legislation in the most beneficial way for a taxpayer; fair consideration of tax disputes; providing complete and reliable information on tax legislation; observance of tax secrecy (Khimicheva, 1997: 102).

The interests of the private and public subject in tax sphere can be classified according to various grounds. For example, the interests of individuals - according to status in tax legal relations of a private subject that bears such interest (taxpayers, tax agents, persons on whom the duties of a taxpayer are imposed, persons participating in tax control procedures, taxpayer representatives, tax authorities, customs authorities, etc.); according to the compliance of interests with legislation (legal and illegal); according to types of needs to which they are directed (property, non-property, own needs, need of others, group and individual needs, etc.); according to the duration of their existence (long-term or temporary ("momentary")); according to their connection with other interests of a subject. Some of the private interests may be "unique", i.e. they are inherent only to a particular single subject-bearer, or "universal" i.e. they are inherent to several or all categories of the subject. For example, private property interests related to obtaining of property benefits from the performance of tax agent duties are absent in the correspondent subjects (tax agents) obliged to calculate, withhold and transfer taxes to the budget, as well as banks that carry out transactions to transfer taxes to the budget are that are obliged to report on the opening or closing of taxpayers accounts; in subjects obliged to transfer information to the tax authorities about registration of certain rights or transactions made by a taxpayer.

A comprehensive study of public interest in tax law will not be complete without an analysis of tax legislation principles. Principles of law - objective properties of law, which are rooted in its content. They reflect the laws of social development, the needs of society in legal regulation. In the opinion of T.S. Boyko, "the principles of regulating of tax relations are fundamental elements that reflect the objective laws of tax relations" (Boiko, 2011: 74). In the frame of this work, the following constitutional principles, which are reflected in the principles and rules of tax legislation, are of the greatest interest:

- the principle of recognition of human and citizen rights and freedoms as the highest value and the principle of their observance and protection by the state (Art. 2 of the Constitution of the Republic of Belarus);

- the principle of the social character of the Belarusian state (Art. 7 of the Constitution of the Republic of Belarus) defines the duty of the state to pursue a certain social policy and bear responsibility for decent life of citizens, regardless of ability to participate in socially useful work (Boiko, 2011: 75). The principles play the role of reference points in legislation formation. An 
emerging legal idea, in a number of cases, is developed in the form of a principle that influences the development of law.

In the future, the legal principle is translated into the rules of legislation. Thus, in the opinion of M.V. Arakelova, "the shift in the balance of interests of private and public subjects towards equality, originally emerged as a legal idea, which then began to find expression in the rules of tax legislation" (Arakelova, 2015: 42).

As one of the manifestations of this trend, one can name the norm from paragraph 7 of Art. 3 of the General Part of the Tax Code, which specifies that "in case of ambiguity or vagueness of tax legislation provisions, state bodies and officials shall make decisions in favor of payers" (Tax Code). While investigating general issues of tax legislation, it is necessary to take into account that its most important tasks are: protection of the property rights of taxpayers from unlimited (in principle) claims of the state and maintaining the balance of public and private interests of tax relations subjects. The very emergence and development of tax legislation are associated with the democratization of society, with the idea of a law-governed state. Principles of justice are becoming more characteristic to Tax law as part of the Belarusian legal system.

The principle of justice is traditionally regarded as the most important. Universal justice is unattainable if we evaluate the event and the phenomenon behind it from the point of view of each participating subject. Speaking about tax relations, those that most corresponds to the balance of interests currently existing in society should be recognized as fair. Public relations, interests of public and private subjects, rules of tax legislation as a result of mutual influence in each period of time tend to the most optimal, to their equilibrium state, which for various reasons is not achieved.

The principle of justice is closely related to the principle of proportionality of taxes, which lies in the optimal balance of budget filling and unfavorable tax consequences for a taxpayer. This principle can also be formulated as a principle of balance of private and public subjects' property interests. This important principle designed to link, coordinate fiscal and stimulating interests of private and public subjects is not adequately reflected in the current tax legislation (Bryzgalin, 1997: 6).

The principle of proportionality could be manifested in the regular specification of tax rates, alongside with the adoption of the law on the budget for the next year, based on the forecasts of the country's economic and social development (Grigorieva, 2009: 32). It should be noted that the principles of tax and budget law are closely connected to tax and budget laws within the framework of the financial law. For example, the principle of proportionality of taxes is related to the principle of the balance of budget, budget legislation, suggesting that the number of budgeted 
expenses should correspond to the total amount of budget income (Art. 8/4 of the Budget Code of the Republic of Belarus) (Budget code).

In accordance with the principle of the public purpose of paying taxes and fees, taxes are established to ensure the solvency of public authorities subjects and should have socially billable character. The state cannot have needs that are different from the needs of society and spend tax revenue for these purposes. This principle develops a provision on the social character of the state, the policy of which is aimed at creating conditions that ensure a decent life and free development of a person, state support for the family, disabled people and elderly citizens, etc. This principle demonstrates the inseparable link between tax legislation and budget legislation within the framework of a single branch of financial law. It is within the budgetary process that deputies, representatives of taxpayers, determine the plans for spending budget funds, control the implementation of budgetary assignments by the executive authorities (Abramchik, 2013: 130).

The principle of the public purpose of paying taxes involves finding a balance of interests of private and public subjects. The property interest of all members of society is embodied in the duty to pay taxes. Therefore, the state has the right and is obliged to take measures to regulate tax legal relations in order to protect the rights and legitimate interests of not only taxpayers but also other members of society. The implementation of the principle of public purpose also implies the consent of a private subject to introduction of tax and his participation in control over the expenditure of funds.

The principle of equal tax burden or the principle of equality is realized in tax legislation not as payment of taxes in the same amount, but as the economic equality of payers and is expressed in the fact that the actual ability to pay tax on the ground of comparison of economic potentials is taken as a basis. The principle of the equal tax burden is to balance public and private interest and to take into account taxpayers economic status to the fullest extent without violating legal equality of taxpayers.

The principle of limiting of specialization of taxes should also be noted. As a general rule, the tax is not intended for targeted expenditure. This is one of the conditions for the stability of the state budget and guarantees that the state fulfills its functions. Target taxes are not completely excluded, but their establishment must be conditioned by significant goals. To introduce a targeted tax, it is necessary to justify, from the constitutional point of view, the need for financing a specific event precisely at the expense of targeted deductions, but not from other sources (Poroshkova, 2007: 59). 
The legal principle of parity of interests of the state and taxpayers is of particular interest (the principle of parity of interests). The essence of this principle is to establish the balance between economic interests of the state and a taxpayer. The principle of parity of interests is based on the idea of smoothing contradictions between interests of the state and taxpayers, which are manifested in the fact that the state seeks to receive as much tax revenue as possible, and the taxpayer to pay as little taxes as possible, as he seeks to save as much income as possible for economic and social development. In these conditions, there is a need to find ways to smooth economic contradictions and highlight the importance of publicity of interests.

Economic equalization of public interest of the state and taxpayers is also carried out through tax administration. Even a slight violation of the balance of these interests leads to a violation not only in the field of taxation but also to causing damage to the state financial (budgetary) activity. It should be noted that in the legal literature judgments have already been expressed that with the adoption of the Tax Code the shift of the balance of rights between public and private subjects towards the latter has become clear.

As an example of the manifestation of the trend of shifting the balance of interests towards a private subject one also should note the fact that the Tax Code of the Republic of Belarus formulates requirements addressed to legislative and law enforcement bodies when adopting and interpreting legislation on taxes and fees. When establishing the requirement to the legislator that the acts of tax legislation should be formulated in the way that everyone knows exactly what taxes (fees), when and in what amount one should pay, the consequences of non-compliance with this requirement are immediately determined: in case of ambiguity or vagueness of the requirements of acts of tax legislation state bodies and officials should make decisions in favor of payers.

Thus, the presumption of the taxpayer's rightness is legislatively determined, when doubts, contradictions, and ambiguities in acts of legislation on taxes are unrecoverable. The implementation of this presumption should allow providing protection of property rights and interests of a taxpayer (Pilipenko, 2006). Since the public interest of all members of society is embodied in the constitutional duty of a taxpayer, the state is not only entitled, but also obliged to take measures to regulate tax relations.

In the opinion of the Constitutional Court of the Republic of Belarus, the types of administrative penalties, the size of the fine, imposed by the Law, allow the enforcers to assign appropriate penalty taking into account the nature and harmful consequences of the committed administrative violation, the circumstances of its commission. The change in the legislative regulation of administrative responsibility 
for violation of procedure of income and property declaring give evidence of legislation liberalization in the field of declaring and is aimed at implementation of the principle of humanism. Ensuring of taxpayers' fulfillment of their constitutional obligation to participate in the financing of public expenditures by paying state taxes, the obligation of natural persons to comply with the requirements of the Declaration law will be exercised through other leverages without bringing these persons to administrative responsibility (Art. 12/1 and Art. 12/7 of Declaration Law). In addition, the Constitutional Court believes that legislator strengthens legal basis for encouraging natural persons to act in compliance with the law, that is expressed in the timely performance of their duties under the Constitution and legislation, which takes into account the interests of society and the state.

From the revealed constitutional and legal sense of the Law, it follows that its provisions are aimed at clarifying of legal regulation in the field of income and property declaring, specifying the rights and obligations of natural persons when declaring income and property at the request of tax authority, process of control activities implementation in this area and are based on the principles and norms of the Constitution. In our opinion, it is necessary to single out the criteria of public interests that are significant from tax and legal point of view, which must be taken into consideration and be settled by tax law. At the same time, not only legally qualified and competent subjects but also procedures, as well as terms for their implementation, should be identified.

\section{Conclusions}

The research carried out led to the conclusion about the necessity of legislative consolidation of the concept of "public interest" in the financial law, defined as social interests recognized by the state, expressed in the rules of financial law and provided with the mechanism of state coercion allowing the development of society and the state. The diversity and multiplicity of functions performed by modern states as well as the incoherence and inconsistency of the goals of various state policies (tax, budget, social, scientific and others) cause plurality and diversity of public interests. Public interest in tax law is manifested in the desire of subjects of tax relations to ensure their legitimate realization, to implement actions aimed at meeting the needs, protecting their rights, receiving material and other benefits, and fulfilling the duties assigned to them by the Constitution of the Republic of Belarus and tax legislation.

Often a particular interest, not explicitly named, is realized in the norms of legislation. However, interest can be embodied in tax legislation. The interdependence of public and private interests leads to the fact that it is difficult or even impossible to 
determine the only subject of a particular interest. Public interests include interest in maintaining a single economic space; interest in the protection of public subject property rights; interest in sharing of tax powers.

It is necessary to find a balance between public and private interests, which include: interest in reducing of tax burden; in return of taxes in the form of social benefits; in protection of property rights of a private subject; in application of tax legislation in the most beneficial way for a taxpayer; in fair consideration of tax disputes; in providing complete and reliable information on tax legislation; in observance of tax secrecy. The use of constitutional principles makes it possible to implement in practice the protection of private property in the implementation of tax relations, to confirm the priority of protection of taxpayer interests while observing the interests of a public subject, to ensure legitimacy in tax legal relations. The analysis carried out showed that tax legislation reflects a trend consisting in shifting of the balance of property interests of public and private subjects of tax relations towards their equality. In this regard, it seems necessary to fix in the Tax Code of the Republic of Belarus, among the main principles of the legislation on taxes and fees, the principle of parity of public interest, which allows achieving harmony in the financial provision of social development.

Since some public interests are not common to all members of society, the complete coincidence of public and social interests is an idea that is not achievable in reality. In tax law, the basic public interest predetermining its system is fiscal interest. At the same time, there are additional public interests, as well as social interests having a general legal, general social significance, that should be taken into account when implementing legal regulation of taxation. For example, for tax law among additional interests and those of general legal significance one can name: the existence of a law-governed state, the priority of universal values; equality and justice; state integrity and security and many others.

\section{References}

Abramchik, L.: Конституционные основы налогового права в Республике Беларусь (Constitutional fundamentals of tax law in the Republic of Belarus, Value paradigm of the Basic Law of the Republic of Belarus), Minsk: BSU, 2013.

Alekseev, S.S.: Теория права (Theory of law), Moscow: BEK, 1995.

Arakelova, M.V.: Баланс частных и публичных интересов при альтернативном разрешении споров, возникающих в налоговых правоотношениях (Balance of private and public interests in alternative resolution of disputes arising in tax legal relations), Финансовое право (Financial Law) no. 11 (2015). 
Boiko, T.S.: Реализация конституционных норм и принципов в налоговом законодательстве Республики Беларусь и решениях Конституционного Суда Республики Беларусь (Realization of constitutional norms and principles in tax legislation of the Republic of Belarus and decisions of the Constitutional Court of the Republic of Belarus), Веснік Канстытуцыйнага Суда Рэспублікі Беларусь (Bulletin of the Constitutional Court of the Republic of Belarus) no. 1 (2011).

Bryzgalin, A.V.: Справедливость как основной принцип налогообложения (Justice as the main principle of taxation), Финансы (Finances) no. 8 (1997).

Chernikova, E.V.: Несколько слов о налоговом патриотизме (A few words about tax patriotism), Современное право (Modern law) no. 4 (2016).

Gavrilchenko, Yu.P.: Правовое регулирование сбережений населения. Теория и практика (Legal regulation of population savings. Theory and practice), Saarbrucken: LAP Lambert Academic Publishing, 2016.

Gracheva, E.Y.: Государственный финансовый контроль как важнейший инструмент обеспечения публичных интересов в условиях рынка (State financial control as an essential tool for ensuring public interests in the market conditions), Вестник университета имени О.Е. Кутафина (МГЮА). Выпуск “Финансовое право” (Bulletin of the University named after O.E. Kutafin (MSAL). Issue "Financial law") no. 4 (2014).

Grigorieva, E.N.: Классификация принципов налогового права (Classification of tax law principles, Actual problems of economic development of the Republic of Belarus and its legal regulation), Minsk: BSEU, 2009.

Gvozdev, V.D., Ryabtsev L.N.: Интересы в праве: теоретические проблемы определения сущности и критериев классификации (Interests in law: theoretical problems of determining the nature and criteria of classification), Право в современном белорусском обществе (Law in contemporary Belarusian society), Minsk: Center for law and pravofinansi. REP, 2013.

Ioffe, O.S.: Обязательственное право (Law of obligations), Moscow: Legal literature, 1975.

Karaseva, M.V.: Современные проблемы построения системы финансового права (Modern problems of financial law system building), Правоведение (Jurisprudence) no. 3 (2006).

Khimicheva, N.I .: Налоговое право (Tax Law), Moscow: BEK, 1997.

Krokhina, Yu.A.: Финансовое право России (Financial Law of Russia), Moscow: Norma, 2014.

Krokhina, Yu.A.: Современные вопросы предмета финансового права (Current Issues of the Subject of Financial Law), Финансовое право (научно-практический журнал Украины), Financial Law (Scientific and Practical Journal of Ukraine) no. 1 (2012).

Leshchenko, S.K.: К вопросу о понятии международного налогового права (On the concept of international tax law), Промышленно-торговое право (Industrial and trade law) no. 5 (2008).

Malko, A.V. (eds): Правовая политика России (общетеоретические и отраслевые проблемы) (Legal policy of Russia (General theoretical and branch problems)), Moscow: Yurlitinform, 2014. 
Public Interest in Financial Law of the Republic of Belarus: Theory and Practice

Maltsev, G.V.: Социальные основания права (The Social foundations of law), Moscow: INFRA-M, Norma, 2011.

Marchenko, M.N.: Теория государства и права (Theory of state and law), Moscow: Publishing House Prospect, 2015.

Nersesyants, V.S.: Общая теория права и государства (General theory of law and state), Moscow: Norma, 2004.

Nogina, O.A.: Государственные внебюджетные фонды в составе бюджетной системы России:проблемы правового регулирования (State extra-budgetary funds within the Russian budget system: problems of legal regulation), Moscow: Statut, 2012.

Pilipenko, A.A.: Теоретико-прикладные аспекты реализации принципа справедливости в налоговом праве (Theoretical and applied aspects of the implementation of the principle of justice in tax law), Духовность, общество, личность, государство (Spirituality, society, personality, state) no. 1 (2006).

Povetkina, N.A.: Бюджетное законодательство Российской Федерации: перспективы развития (Budget legislation of the Russian Federation: prospects for development), Финансовое право (Financial law) no. 9 (2015).

Poroshkova, T.A.: Меры и способы защиты публичных интересов в налоговых правоотношениях (Measures and ways to protect public interests in tax legal relations), Налоговые споры: теория и практика (Tax disputes: theory and practice) no. 9 (2007).

Rabets, A.M.: Соотношение частных и публичных интересов в сфере государственной поддержки семьи в Российской Федерации (The correlation of private and public interests in the sphere of state support of family in the Russian Federation), 2016. www.naukarastudent.ru.

Shershenevich, G.F.: Учебник русского гражданского права (The Textbook of Russian civil law), Moscow: Spark, 1995.

Sheveleva, N.A.: Баланс частных и публичных интересов (Balance of private and public interests), Конституция Российской Федерации (The Constitution Of The Russian Federation), Moscow: Norma, 2009.

Spector, E.I. (eds.): Публичные и частные интересы в финансовом праве (Public and private interests in financial law), Moscow: Norma, 2011.

Tikhomirov, Yu.A.: Публичное право (Public Law), Moscow: Publishing House BEK, 1995.

Vasilevich, G.A.: Конституция Республики Беларусь: научно -практический комментарий (The Constitution of the Republic of Belarus: scientific and practical comment), Minsk: State Institute of Management and Social Technologies of the Belarusian State University, 2005.

Vitushko, V.A.: Теория механизма правового регулирования экономических отношений (Theory of the mechanism of legal regulation of economic relations) Doctor (higher doctorate) Thesis, Minsk: Belarusian State University, 2001.

Zapolsky, S.V.: Дискуссионные вопросы теории финансового права (Discussion questions of the theory of financial law), Moscow: Eksmo, 2008. 
BY: Constitution of the Republic of Belarus of 24 November 1996.

BY: Act no. 412-3/2008 - Budget Code of the Republic of Belarus.

BY: Act no. 1660-3/2002 - Tax Code.

BY: Resolution of the Council of Ministers no. 18/2017, A set of measures to implement the main directions of social and economic development of the Republic of Belarus for 2016-2020.

BY: Decisions of the Constitutional Court of 23 December 2009 no. P-412/2009.

BY: Decisions of the Constitutional Court of 24 December 2014 no. P-962/2014.

BY: Decisions of the Constitutional Court of 28 December 2015 no. P-1017/2015. 